\title{
PATHS TO OWNERSHIP OF SMALL BUSINESSES AMONG IMMIGRANTS IN ISRAELI CITIES AND TOWNS
}

\author{
Eran Razin*
}

\begin{abstract}
This paper examines the role of location and ethnicity in paths to entrepreneurship among immigrants in Israel, focusing on differences between immigrants of Eastern (Middle Eastern and North African) and Western (European and American) origin, and between metropolitan and nonmetropolitan locations. Analysis is based on census data for cohorts of immigrants defined by age and year of immigration and on a survey of blue-collar and distribution small businesses. The combination of a population of Eastern origin and peripheral location created the most restricted paths to entrepreneurship. These paths were characterized by a high dependency on kinship and social networks for advancement through blue-collar and distribution self-employment opportunities in locations where such opportunities and supportive networks were least available.
\end{abstract}

\section{INTRODUCTION}

Promoting the small business economy has been a major element in local development strategies, which have become increasingly popular since the 1970s. The success of such efforts depends on broad geographic and economic factors influencing the opportunity structure for entrepreneurs. However, examination of conditions and processes influencing entrepreneurship in various locations cannot be limited to such factors, since entrepreneurship is to a large extent a social phenomenon associated with kinship and wider social networks. Entrepreneurship has particularly served immigrant groups as an upward economic mobility route, and ethnicity has been a major dimension correlated with entrepreneurship in immigration-absorbing countries.

The aim of this paper is to identify paths to entrepreneurship among immigrants in Israel, emphasizing the role of location and ethnicity. It is assumed that shifts in the local composition of small businesses have involved mainly the entrance of new immigrant groups or young age cohorts into the labor market, whereas the occupational and spatial mobility of those already in the Israeli labor market has been limited. Thus, the entrepreneurial behavior of groups entering the labor market is most significant in understanding shifts in local economies.

\footnotetext{
*Department of Geography, The Hebrew University, Jerusalem, Israel. This study was supported by grants from the Israel Foundation Trustees and from the Fund for Basic Research administered by the Israel Academy of Sciences and Humanities.
} 
It is argued that entrepreneurship has played a different role in the mobility routes of Israel's two major immigrant groups: those from Middle Eastern and North African countries, who tended to enter the Israeli labor market at the bottom levels; and those from European and American countries, who came with qualifications and contacts that enabled them to begin at higher levels of the occupational ladder. Thus, the influence of place of residence on paths to business ownership differed among the two groups. This paper focuses on differences between Israeli metropolitan areas and nonmetropolitan development towns for local opportunities, personal qualifications, and resources and entrepreneurial networks. Insights from three separate analyses are provided, based on census data for various immigrant groups and on a survey of blue-collar and distribution small businesses. These analyses demonstrate the significance of the social-ethnic dimension in devising local entrepreneurial development policies and the significance of location in immigrant absorption policies. Particularly emphasized is the inferior position of potential entrepreneurs of Middle Eastern and North African origin in nonmetropolitan development towns.

\section{LOCAL SMALL BUSINESS ECONOMIES AND IMMIGRANT ENTREPRENEURS}

Economic instability, uncertainty, and structural change have led to the resurgence of the small business sector in Western economies since the 1970s (Birch 1987; Brock and Evans 1989; Storper and Scott 1989). The magnitude of this change and its long-term continuity are in debate (Amin and Robins 1990). Nevertheless, there has been a pronounced shift of local development policies from nationally backed, large-scale capital incentives toward efforts made by local authorities to focus more on the small business economy (Campbell 1990; Harvey 1989; Razin 1990b). Entrepreneurial development policies, dealing with access to capital, management skills, information on supplier and buyer markets, and the political climate facing small firms, have all been under the financial confines of local authorities. Various programs such as small business loan funds and incubator projects have been cost-effective means of creating jobs in Israel when they are well targeted spatially or sectorally (Felsenstein 1992). Hence, frequent proposals have stressed the need to improve Israel's business climate for entrepreneurs by revising tax laws and regulations and by restricting bureaucratic prerogatives and unfair competition of public, semi-public, and not-for-profit organizations (Greenwood 1990).

Prospects of business formation depend on location. Business formation opportunities in manufacturing, for example, decrease with distance from 
metropolitan areas in Israel, whereas such opportunities in retail depend on the local purchasing power and are also influenced positively by a large local tourism sector (Razin 1990a). However, as manifested in cultural theories of entrepreneurship (Sombart 1913) and in those emphasizing tradition of enterprise (Rischin 1962), entrepreneurship depends not only on local opportunities, but also on the local supply of potential entrepreneurs. A typical example is the attempt of development policies in southem Italy to replicate the success of local economies in "Third Italy," which have been based on small-scale, flourishing enterprises. The attempt was doomed to fail since the Mezzogiomo lacked the particular social structure and tradition of enterprise responsible for successful enterprise in "Third Italy" (Bamford 1987; Martinelli 1985).

The supply of entrepreneurs is largely a function of human capital and financial resources of the local population (Bingham and Melkers 1989). Nevertheless, entrepreneurial skills are often acquired through personal contacts and acquaintanceship with other entrepreneurs (Zimmer and Aldrich 1987). Family contacts and community networks are of vital importance in utilizing entrepreneurial opportunities. Common policy tools to assist entrepreneurship have failed to reach fundamental characteristics of the community that cause entrepreneurship, such as the presence of entrepreneurial culture and a diversity of organizations, resources, and information networks. Hence, the policies could have had a considerable effect mainly in places where entrepreneurship was already rooted (Mokrey 1988).

The social foundations of entrepreneurship should therefore be addressed when devising policies for local entrepreneurial development. The major role of ethnicity in these foundations (Razin 1989, 1990c) is largely a consequence of social networks following ethnic lines. Entrepreneurial networks have been utilized by immigrant groups who faced barriers for advancement as employees (Portes 1981). Typical North American models of the integration of foreign immigrants assume that immigrant groups follow a similar course, which may take several generations, depending on the class and educational backgrounds of the first generation (Glazer and Moynihan 1970). When poorly educated immigrants arrive, they take the lowest-level jobs. Their children move into more skilled positions, and their grandchildren increasingly take professional, managerial, and technical positions (McCarthy and Valdez 1986). Entrepreneurship may have a major role in immigrant advancement, particularly at the intermediate stage, because it can pull immigrants up from bottom-level jobs and open the way to white-collar professional occupations for the next generation. Nevertheless, not all groups progress at the same pace, and the more successful groups usually achieve major gains during the first generation. The most successful entry of immigrants into the American labor market has frequently been through 
entrepreneurial activity, when immigrants used local ethnic ties and place-specific opportunities for business growth (Portes and Bach 1985).

The role of entrepreneurship in the mobility routes of immigrants in Israel has been influenced by several factors not found in the American model. The greater dependency of immigrants in Israel on public absorbing agencies, as well as prevailing assimilationist ideologies that emphasized common Jewish-Israeli identity over ethno-cultural diversity, could have been counterproductive to the formation of ethnic-based entrepreneurial networks (Razin and Langlois 1992). Moreover, Zionist-socialist ideology viewed the extraordinary inclination of Jews in the diaspora toward entrepreneurship as a function of external constraints, rather than as a valuable asset to be exploited locally (Tamari 1991). Still, immigrants in Israel did not face any discriminatory legal constraints in establishing businesses such as those experienced by certain groups in some areas of continental Europe (Gildas 1990). Thus, entrepreneurship could have played a significant role in their assimilation, even if to a lesser magnitude than for some groups in the United States.

\section{THE ISRAELI STUDY GROUPS - MAJOR ARGUMENTS}

Immigrants in Israel can be divided broadly into two major groups: Jews of Western, mostly European, origin, and Jews of Eastern, mostly Middle Eastern and North African, origin (Eisenstadt 1985). Immigrants of European origin enjoyed better qualifications and closer ethnic and cultural familiarity with the pre1948 mainstream Jewish population. Thus, they were better equipped to advance in the new country than immigrants of Eastern origin, who were also more prone to various kinds of discrimination.

It is argued that immigrants of Eastern origin followed different entrepreneurial paths than those of Western origin. The former tended to enter the bottom levels of the Israeli labor market and might have increasingly utilized blue-collar and distribution entrepreneurial niches for advancement. This route could have been utilized more by those immigrating as children, since they adjust more easily to a new country. By following this route, immigrants could overcome their strong dependency on the government for job provision. Among immigrants of Western origin, an opposite trend could be expected. The older immigrants came from Europe with a tradition of petty enterprise and with much better contacts and qualifications to implement this tradition in Israel than expetty entrepreneurs from Middle Eastem and North African countries. However, those immigrating as children presumably tended to exit from petty entrepreneurial occupations, such as retail, to white-collar, salaried jobs. If still 
tuming to self-employment, they could have increasingly moved to operate larger businesses as well as businesses requiring white-collar professional qualifications.

Extensive utilization of blue-collar and distribution entrepreneurial niches by immigrants of Eastern origin can be expected to be associated with residence in Israel's largest metropolis, Tel Aviv. Israel's metropolitan areas are characterized by extensive entrepreneurial networks that are based on business and ethnic ties and provide maximal diversity of entrepreneurial opportunities and opportunities to gain experience as salaried workers. Entrepreneurial networks in metropolitan areas are extensive and dynamic and are dominated by business-oriented local ties. Ethic entrepreneurial networks can be immense. The contribution of human capital attributes to business formation can also be greater in central locations.

Entrepreneurial networks in noncentral towns can be based mostly on stable, local, social ties, becoming narrower and restricted primarily to immediate family ties in small peripheral localities (Johannisson 1988). Self-employment opportunities in small nonmetropolitan development towns in Israel have been limited and relatively concentrated in retail and construction (Razin 1990a). Those relatively few opportunities were quickly filled, leaving little room for penetration by the younger generation into the small business economy. Israel's population dispersal policy progressed during the 1950 s and 1960 s mainly by the dispersion of immigrants to peripheral localities, which could have influenced the prospects of entrepreneurship among immigrants. The dispersion level of an immigrant group depended on the specific timing of its mass arrival (Lissak 1986), as well as on its socioeconomic status, which determined its ability to adjust in space. Both factors worked to increase the concentration of weaker Eastern origin immigrants in nonmetropolitan development towns. Thus, the population dispersal policy could have reduced the ability of these immigrants to advance through entrepreneurship.

The less dispersed spatial distribution of immigrants of Westem origin could be advantageous for entrepreneurship. Moreover, the increasing inclination of these immigrants toward the formation of businesses based more on human capital can also modify the role of location. Many of these businesses cater to the needs of Israel's large corporations and wealthy population and thus gravitate to the Tel Aviv metropolitan area. However, in general, the self-employed immigrants from Europe could have enjoyed greater locational flexibility because they are less dependent on kinship and ethnic networks and perhaps more oriented to white-collar entrepreneurial opportunities in Jerusalem and in other localities.

Whereas the above hypotheses stress the major distinction between immigrants of Western and Eastern origins, the examination of paths to ownership of small businesses should refer in detail to countries of birth. Supportive entrepreneurial networks among immigrants correspond to specific origin groups, and Eastem origin immigrants have particularly retained their specific ethnic 
identity and ethnic-based networks (Maman 1991). Personal attributes also vary significantly across specific countries of origin, as do the geographical patterns of settlement in Israel. It is beyond the scope of this paper to address specific arguments for each immigrant group. Rather, the paper seeks to demonstrate the ethnic specificity of entrepreneurial patterns by breaking down the two major origin groups into detailed countries of birth.

In sum, this paper argues that the influence of location on business ownership among immigrants depends on the particular role of entrepreneurship in the mobility route of the immigrant group. The residential pattern of an immigrant group, while influencing the local supply of potential entrepreneurs, also influences markedly the ability of the immigrant group to advance through entrepreneurship.

\section{DATA AND METHODOLOGY}

The paper is based on insights from three analyses, each referring to different data sets and subpopulations. It focuses on confirming arguments by using supportive evidence from different analyses, rather than by presenting the complete statistical analyses. The first analysis treats the role of self-employment in the mobility routes of immigrants who arrived in Israel during the period 1948-1954 from nine major origins: Iraq, Yemen, Iran, Turkey, Morocco, Poland, Rumania, Bulgaria and Greece, and Czechoslovakia. These immigrants came to a new and economically weak country, which had absorbed in these few years a mass immigration that outnumbered its previous population and which was unable to supply permanent housing and jobs for many of them for years. For each of these countries of birth, two age cohorts are analyzed: those born between 1918 and 1927, and those born between 1933 and 1942. Thus, those immigrating as adults with prior work experience are distinguished from those coming as children who began working in Israel. These definitions give 18 specific cohorts composed of immigrants of similar age, country of birth, and period of immigration. ${ }^{1}$ The changing role of each cohort in the labor market is examined in the population censuses of 1961, 1972, and 1983.

Results are compared to those of a second census analysis of immigrants who arrived during the period 1972-1983, came from middle-class backgrounds, and arrived in a much wealthier welfare state. Details of this analysis are presented elsewhere (Razin and Langlois 1992), and only several findings are quoted here for the purpose of comparison. Finally, business formation in bluecollar and distribution activities is examined. This area is frequently utilized as an upward mobility route by immigrants lacking qualifications and the contacts 
necessary to advance as employees. This section is based on insights from a survey of 421 small businesses conducted by the author in 1989-1990 in a metropolitan city (Holon) and in four nonmetropolitan towns (Yavne, Ashqelon, Ofaqim, and Qiryat Shemona). Only partial results of the survey are described here, due to space limitation. Data on interethnic variations are presented in greater detail in Razin (1991a).

\section{SELF-EMPLOYMENT IN THE MOBILITY ROUTES OF IMMIGRANTS ARRIVING BETWEEN 1948 AND 1954}

A general examination of interethnic variations in rates of self-employment reveals that immigrants of Western origin had much higher rates of self-employment than those of Eastern origin, but this gap had completely disappeared by 1983 (Nahon 1989; Razin 1989). The rapid decline in the rate of self-employment among the most entrepreneurial groups in 1961 (Table 1) partly reflects the general decline in the rate of self-employment in the Israeli economy (Razin 1990b). The convergence of rates of self-employment of immigrants from Western and Eastern origins can be explained by the changing role of selfemployment in their occupational mobility, as discussed below. Still, great variations in the propensity to become self-employed existed among subgroups of each of the two main origin groups. In 1983, immigrants who originated in Eastern countries occupied both extremes of most and least entrepreneurial groups in Israel (Table 1), a fact reflecting their greater retention of specific ethnic networks as well as their greater variations in human capital attributes and geographical distribution.

The role of self-employment in the occupational mobility of immigrants of Eastern origin coming to Israel during the years 1948-1954 differed considerably from that role among European immigrants (Figure 1). Among the groups of Eastern origin, those immigrating as children (born 1933-1942) tended to become self-employed more than those immigrating as adults (bom 1918-1927). In contrast, among groups of European origin, those immigrating as adults tended to become self-employed more than those coming as children (Figure 1). Thus, among adult immigrants, who mostly had prior work experience in their origin country, European immigrants were more entrepreneurial than Eastem immigrants, whereas among those immigrating as children, the opposite was true.

Entrepreneurial activities performed by immigrants also differed between Eastern and European origin groups (Figure 2). The period 1961-1983 is distinguished by a sharp increase in the proportion of business and other services among the urban self-employed in Israel versus a decline in manufacturing and in 
TABLE 1

Israel's Most and Least Entrepreneurial Origin Groups, 1961-1983

(\% self-employed)

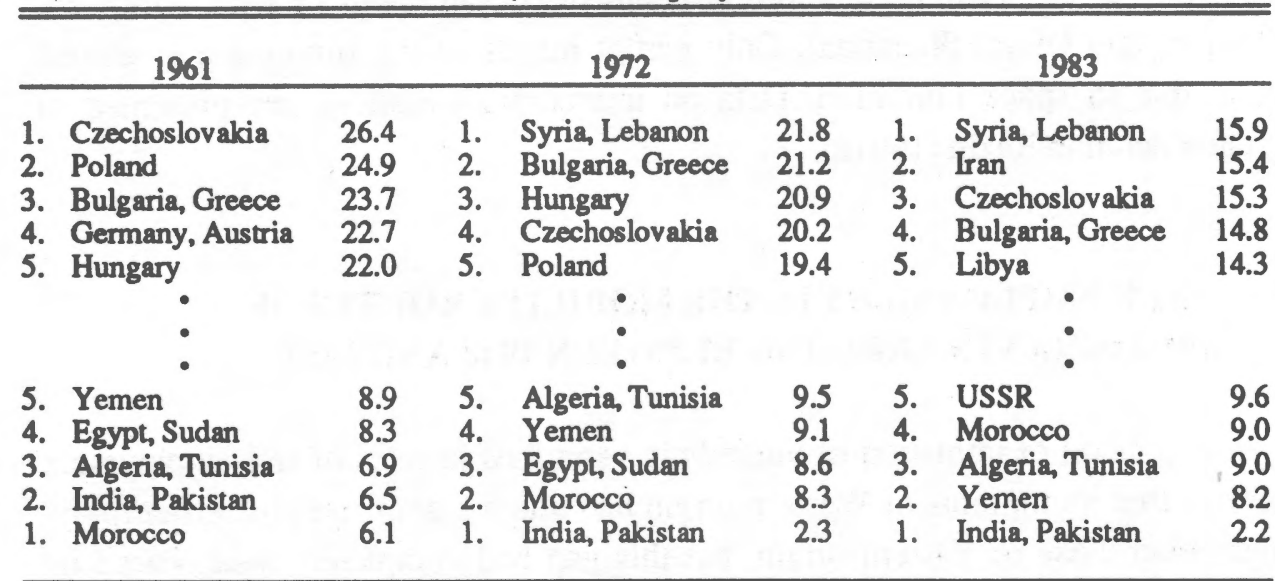

Origin group - Country of birth for foreign born and father's country of birth for Israeli born.

Source: Censuses of Population and Housing.

retail establishments in the food sector (Razin 1990a). However, on the backdrop of this general trend, immigrants of Eastern and European origins followed different paths. Among the self-employed immigrants of Eastern origin, those arriving as children were less likely to engage in retail and more likely to work in blue-collar and distribution activities (manufacturing, car repair shops, construction, transportation) than those immigrating as adults. Thus, the trend among that group was to seek opportunities that did not require high levels of formal education. Among self-employed European immigrants, those immigrating as children were also less likely to engage in retail than were older immigrants. However, the major trend among them was to engage in professional white-collar services, rather than retail, blue-collar, and distribution activities, and the young European immigrants also retained a much higher propensity to engage in large businesses than young Eastern origin immigrants.

The geographical distribution of the working population of each immigrant group during the period 1961-1983 was remarkably stable (Razin 1991b). It seems that immigrants of most groups rarely moved from the metropolitan area or nonmetropolitan town where they had settled shortly after immigrating to Israel. Rates of migration were not significantly correlated with country of birth, despite the wide variations among immigrant groups in the initial geographical distributions, from the high concentration of Bulgarian and Greeks in the Tel Aviv metropolitan area to the wide dispersal of Moroccans throughout the country. Hence, the initial residential pattern of new immigrants in Israel had a long-term impact on their subsequent role in the labor market. 


\section{FIGURE 1}

Rates of Self-Employment among Immigrants of 1948-1954, by Major Countries of Birth and Age Cohorts, 1961-1983.
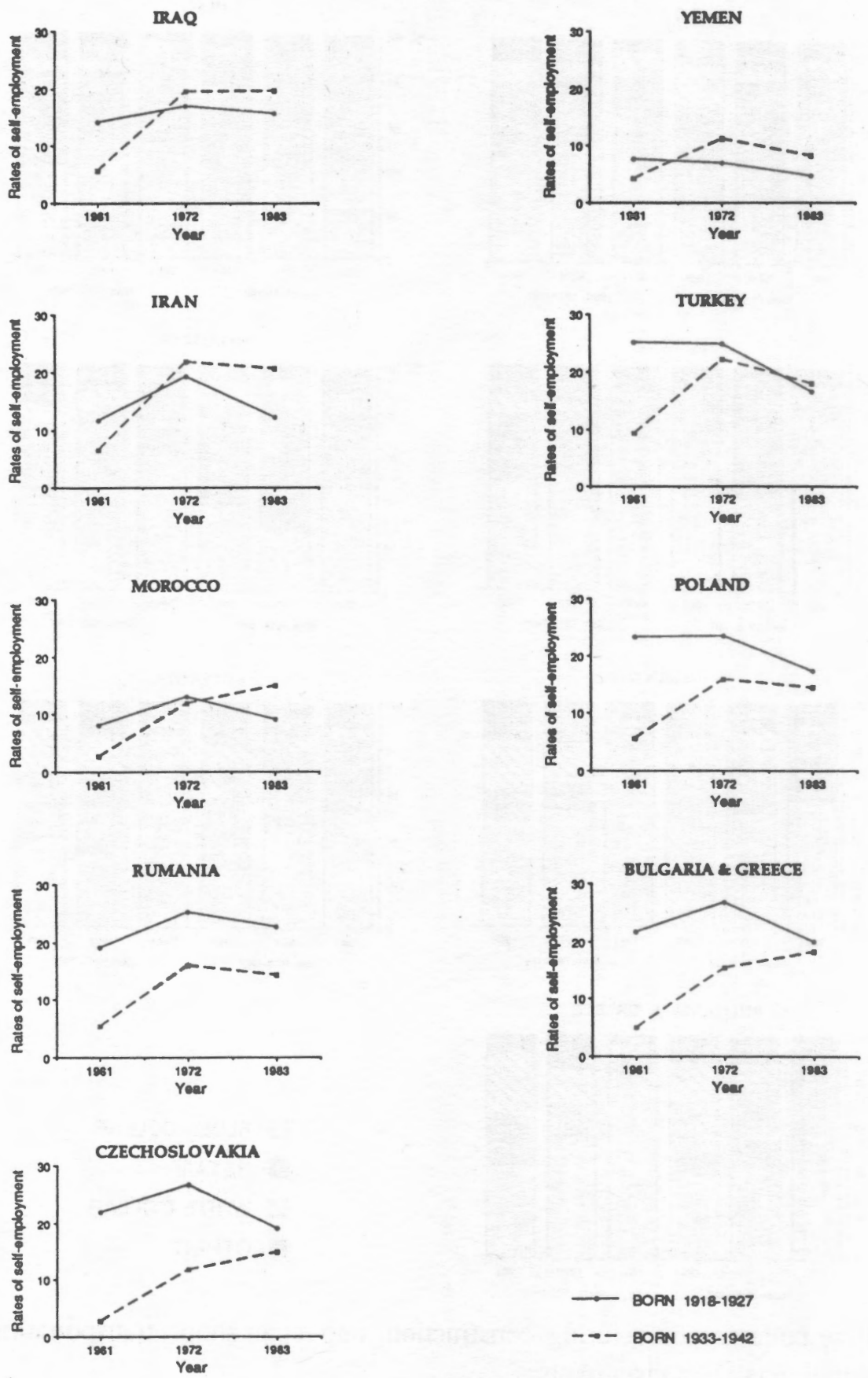

Source: Censuses of Population and Housing. 


\section{FIGURE 2}

Immigrants of 1948-1954: The Self-Employed by Major Industries, Countries of Birth, and Age Cohorts, 1961-1983.

IRAO

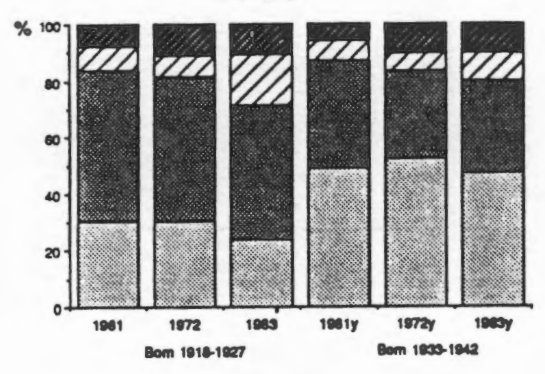

TURKEY

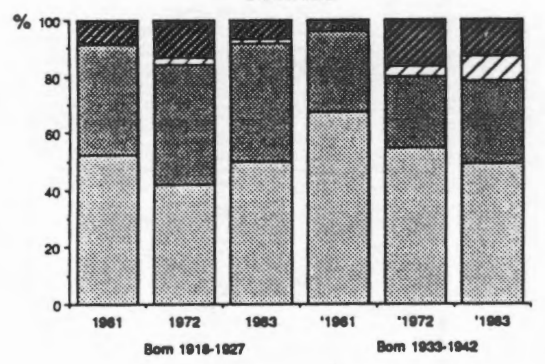

POLAND

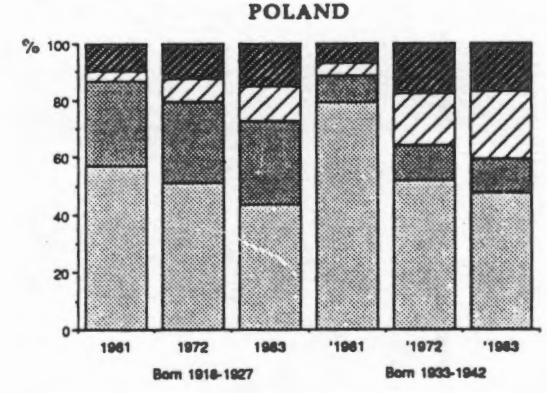

BULGARIA \& GREECE

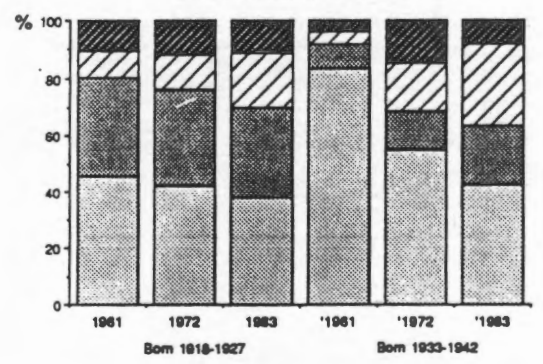

IRAN

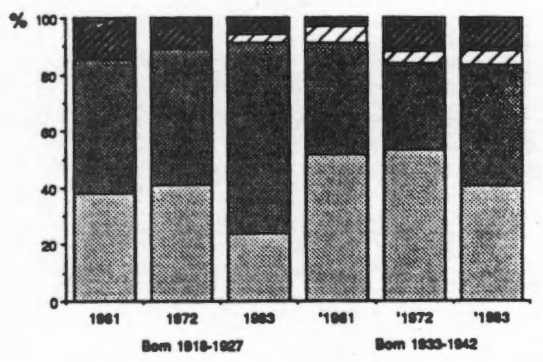

MOROCCO


Blue-collar: manufacturing, construction, auto repair shops, transportation. Retail: retail and restaurants.

White-collar: business and public services. 
Stability also characterized rates of self-employment among each immigrant group in each location. Apparently, in most cases, the decision to become selfemployed was made at an early stage of the work history. As expected, nearly all groups had higher rates of self-employment in metropolitan areas, particularly in the Tel Aviv metropolis. The high rates of self-employment in Tel Aviv, compared to other metropolitan areas and development towns, characterized particularly those immigrating as children from Eastem countries (Table 2). It seems that the mobility route of immigrants of Eastern origin as self-employed in bluecollar and distribution activities depended heavily on residence in the Tel Aviv metropolis.

The self-employed of all groups were more concentrated in retail in development towns than in the Tel Aviv metropolis (Figure 3). The concentration in retail in development towns was particularly prominent for the older immigrants of Eastern origin. Self-employment of the younger cohort of immigrants of Eastern origin in the Tel Aviv metropolis concentrated in blue-collar activities more than any other major group (Figure 3). The occupational composition among the young cohort of self-employed European immigrants was similar in Tel Aviv and in the development towns, indicating the smaller influence of location on the entrepreneurial mobility routes of European origin immigrants.

\section{SELF-EMPLOYMENT AMONG IMMIGRANTS OF 1972-1983}

The immigrants of the 1970s penetrated different self-employment opportunities than those attracting earlier immigrants. These immigrants were overrepresented in white-collar self-employment occupations and underrepresented in activities serving as typical niches for immigrant entrepreneurs, such as construction and food services (Razin and Langlois 1992). Self-employed immigrants from developed countries gravitated particularly toward white-collar services, which accounted for as much as 70 percent of the self-employed in the case of North American immigrants. Immigrants from North Africa, Asia, and particularly Iran were at the other extreme-underrepresented in professional services and overrepresented in retail.

New immigrants in the Tel Aviv and Jerusalem metropolitan areas had higher rates of self-employment than new immigrants in other locations. But unlike the general labor force, immigrants tended most to become self-employed in Jerusalem. A log-linear model (Razin and Langlois 1992) indicated that the lower educated and those coming from Asian and African origins tended to concentrate in self-employed distribution activities. These immigrants tended to cluster in the largest and most diversified metropolitan area-Tel Aviv, where particular con- 
TABLE 2

Rates of Self-Employment among Immigrants of 1948-1954 by Major Countries of Birth, Selected Urban Areas of Residence, and Age Cohorts, 1983

\begin{tabular}{|c|c|c|c|c|}
\hline $\begin{array}{l}\text { Country } \\
\text { of Birth }\end{array}$ & $\begin{array}{c}\text { Tel Aviv } \\
\text { Metro. }\end{array}$ & $\begin{array}{l}\text { Haifa } \\
\text { Metro. }\end{array}$ & $\begin{array}{l}\text { Jerusalem } \\
\text { Metro. }\end{array}$ & $\begin{array}{l}\text { Development } \\
\text { Towns }\end{array}$ \\
\hline
\end{tabular}

Bom in 1918-1927

$\begin{array}{lrccr}\text { Iraq } & 15.6 & 17.5 & 16.9 & 11.7 \\ \text { Yemen } & 4.7 & 0 & 0 . & (3.1) \\ \text { Iran } & 11.7 & (3.1) & 12.1 & \vdots \\ \text { Turkey } & 19.8 & (3.1) & (5.9) & . \\ \text { Morocco } & 13.4 & 9.5 & 5.7 & 10.5 \\ \text { Poland } & 19.0 & 12.3 & 15.7 & 5.3 \\ \text { Rumania } & 21.1 & 24.3 & (11.8) & 17.0 \\ \text { Bulgaria \& Greece } & 19.2 & 26.0 & 0 . & \vdots \\ \text { Czechoslovakia } & 22.7 & 13.2 & (0) & 0\end{array}$

Bom in 1933-1942

\begin{tabular}{lcccc} 
Iraq & 22.8 & 12.6 & 16.4 & 11.6 \\
Yemen & 9.3 & $(0)$ & $(6.4)$ & 2.2 \\
Iran & 21.6 & 0.6 & 18.4 & 13.1 \\
Turkey & 21.9 & 8.6 & 8.1 & 8.8 \\
Morocco & 20.0 & 15.9 & 11.4 & 11.0 \\
Poland & 15.6 & 12.1 & $(8.1)$ & 16.0 \\
Rumania & 15.2 & 13.1 & $(10.2)$ & 13.5 \\
Bulgaria \& Greece & 19.0 & 13.2 & $(23.3)$ & $(16.7)$ \\
Czechoslovakia & 16.4 &.- &.- & 0 \\
\hline
\end{tabular}

( ) Less than 50 in the sample.

- Less than 24 in the sample.

Nonmetropolitan new towns (populated after 1948) in the coastal plain and development towns in the periphery, not including Beer Sheva.

Source: Census of Population and Housing, 1983.

centrations among self-employed immigrants evolved in manufacturing and wholesale. Groups who preferred white-collar services were more prominent in Jerusalem, which offered ample self-employment opportunities in white-collar professional services because of its role as Israel's capital and its extraordinarily large public services sector. Self-employment might have been attractive to these immigrants because of their difficulties in obtaining senior salaried jobs and their lack of necessary contacts to help them compete over the few professional job vacancies in Jerusalem's labor market, which is characterized by high rates of job tenure and low employee turnover.

The Israeli development towns offered inferior opportunities for entrepreneurship. A relatively high proportion (24.3 percent) of the economically 


\section{FIGURE 3}

Immigrants of 1948-1954: The Self-Employed in the

Tel Aviv Metropolis and the Development Towns by Major Industries, Countries of Birth, and Age Cohorts, 1983.

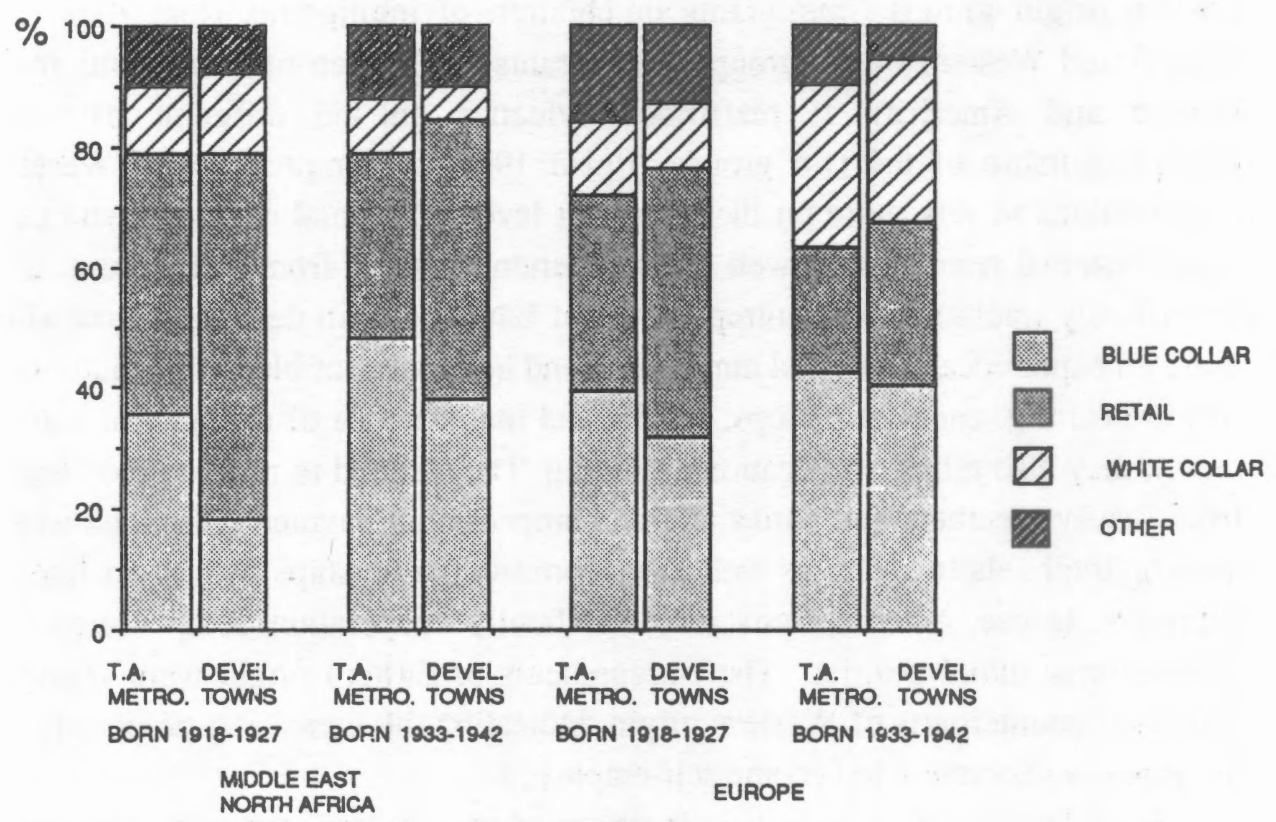

Development towns: new towns in the coastal plain, development towns in the periphery, Beer Sheva.

Middle East-North Africa: Iraq, Yemen, Iran, Turkey, Morocco.

Europe: Poland, Rumania, Bulgaria, Greece, Czechoslovakia.

active immigrants of 1972-1983 lived in development towns in 1983, which might have impeded their prospects for entrepreneurship. The disadvantage of development towns was particularly evident for immigrants from Asia, Africa, the USSR, and Rumania, probably due to the lack of sufficient self-employment opportunities in the distribution sector. Rates of self-employment among immigrants from Europe and America in development towns were comparable to those in the Tel Aviv and Jerusalem metropolitan areas. These immigrant groups could enter the small niche of white-collar services in these towns with very little competition from the local veteran population, since native Israelis possessing professional skills rarely chose to live in development towns. Thus, in the case of the development towns, it seems that the niche open for immigrant entrepreneurs was exactly the one presenting the major disadvantage of the development towns (Razin and Langlois 1992). 


\section{PATHS TO ENTREPRENEURSHIP IN METROPOLITAN AND NONMETROPOLITAN TOWNS}

The small business survey referred only to the general distinction between Eastern origin groups (immigrants or children of immigrants from Asia and Africa) and Western origin groups (immigrants or children of immigrants from Europe and America). It reaffirmed evidence on the different paths to entrepreneurship of the two groups (Razin 1991a). Entrepreneurs of Western origin tended to rely more on their superior levels of formal education and personal financial resources, as well as on experience gained from their parents and their family traditions. The entrepreneurs of Eastern origin depended somewhat more on experience as salaried employees, and in the case of blue-collar activities (manufacturing, car repair shops, repairs and maintenance of mechanical equipment), they also relied on vocational training. They tended to rely more on loans from family members and banks and on compensation payments received when quitting their salaried jobs, as well as on forming partnerships with other family members. Hence, external assistance and family cooperation compensated for their inferior initial position. The entrepreneurs of Eastern origin were younger than their counterparts of Western origin, indicating the increasing propensity of the younger generation to become self-employed.

Spatial variations in paths to entrepreneurship were less consistent than interethnic variations. The role of location was prominent in determining the industrial structure of the small business sector, but when businesses of similar industries were compared, ethnicity had a greater impact on paths to entrepreneurship and on traits of small businesses. Still, business formation in nonmetropolitan towns depended more heavily on the support and cooperation of family members. Experience gained from parents and other family members, as well as loans from family members and family partnerships in the case of blue-collar activities, were more common in nonmetropolitan towns. In the two remote development towns included in the survey, a particularly high percentage of blue-collar small business owners had self-employed parents and brothers. Moreover, the first clients of these businesses were more frequently reached through relatives and social acquaintances (Table 3). Business owners in nonmetropolitan areas also depended more on bank loans and on experience gained in the army or through vocational training. On the other hand, business owners in Holon were older and more experienced, had depended more on personal resources for establishing the business, and had higher levels of education. The choice of entrepreneurial activity in Holon depended more on previous professions and expertise, whereas in nonmetropolitan towns, more business owners expressed a love for their chosen activity or identified a function missing in town. The large share of women engaged 
in retail in nonmetropolitan towns could have been a consequence of the absence of attractive salaried jobs in these towns. Holon offered the most thriving and dynamic environment for small businesses. Business owners in Holon were least likely to complain about making "the mistake of their life" or being "young and foolish" when opening their businesses. Active marketing and previous business contacts were more important in Holon for attracting first-time clients (Table 3).

Most small business owners in nonmetropolitan towns were long-time residents of the town or its vicinity before becoming self-employed, whereas in Holon, a higher proportion (in blue-collar activities) migrated from other localities or commuted from fairly distant localities. Thus, business owners in Holon more often quoted availability of a suitable site and proximity to clients as location factors, whereas in the periphery, the place of residence had the overwhelming role in the location decision (Table 3). The dependency on place of residence as a sole location factor in nonmetropolitan towns was particularly prominent among business owners of Eastem origin.

\section{CONCLUSIONS}

Paths to entrepreneurship were found to be clearly correlated with ethnic origin. Younger cohorts of immigrants from Eastern (Asian and African) origin increasingly tended to enter distribution and blue-collar entrepreneurial activities that do not require high levels of formal education. Younger cohorts of immigrants from Western (European and American) origin, on the other hand, tended to leave the self-employment sector or to operate larger businesses and businesses in professional white-collar services. The entrepreneurs of Eastem origin suffered from inferior levels of education and professional qualifications and from a lack of financial resources and a tradition of family enterprise. Family cooperation was a common means to overcome this inferior situation, and the self-employed of Eastern origin tended to be in families where a large proportion of their generation turned to self-employment. Entrepreneurs of Eastern origin also depended more than entrepreneurs of Western origin on bank loans, vocational training, and experience gained as salaried employees, and they were more restricted to local opportunities for business formation.

These differences, as well as variations among specific ethnic groups, are most significant for local entrepreneurial development policies. The ethnic composition of the labor force varies greatly among localities. Typical paths to entrepreneurship differ from place to place, as does the potential for entrepreneurial development and bottlenecks requiring public intervention. This role of ethnicity is particularly critical when proposing public intervention tools in 
TABLE 3

Business Owners in Blue-Collar and Distribution Activities by Town and Selected Characteristics of the Business and Its Owner, 1989/90 (in percentages)

\begin{tabular}{|c|c|c|c|c|}
\hline \multirow{2}{*}{$+\quad$} & \multicolumn{2}{|c|}{ Blue-collar ${ }^{2}$} & \multicolumn{2}{|c|}{ Distribution $^{\mathrm{b}}$} \\
\hline & Holon & $\begin{array}{l}\text { Non-metr. } \\
\text { townsc }\end{array}$ & Holon & $\begin{array}{c}\text { Non-metr. } \\
\text { towns }\end{array}$ \\
\hline Sex $\%$ females & 1.7 & 1.4 & 12.8 & 34.0 \\
\hline $\begin{array}{l}\text { Age } \\
22-44 \\
55+\end{array}$ & $\begin{array}{l}50.9 \\
24.6\end{array}$ & $\begin{array}{r}72.2 \\
9.7\end{array}$ & $\begin{array}{l}50.0 \\
23.1\end{array}$ & $\begin{array}{l}66.5 \\
20.6\end{array}$ \\
\hline $\begin{array}{l}\text { Choice of industry } \\
\text { Personal preference } \\
\text { Profession/skills } \\
\text { A function missing in town }\end{array}$ & $\begin{array}{r}10.4 \\
67.8 \\
3.5\end{array}$ & $\begin{array}{l}12.9 \\
55.7 \\
11.4\end{array}$ & $\begin{array}{r}14.1 \\
46.2 \\
7.7\end{array}$ & $\begin{array}{l}25.0 \\
30.3 \\
13.2\end{array}$ \\
\hline $\begin{array}{l}\text { Choice of town } \\
\text { Place of residence } \\
\text { Location and site advantages }\end{array}$ & $\begin{array}{l}31.3 \\
47.0\end{array}$ & $\begin{array}{l}63.2 \\
22.1\end{array}$ & $\begin{array}{l}37.2 \\
42.3\end{array}$ & $\begin{array}{l}60.8 \\
25.5\end{array}$ \\
\hline $\begin{array}{l}\text { Sources of entrep. skills } \\
\text { Parents } \\
\text { Other family members } \\
\text { Army } \\
\text { Vocational training }\end{array}$ & $\begin{array}{l}4.3 \\
1.7 \\
1.7 \\
9.6\end{array}$ & $\begin{array}{r}9.9 \\
4.2 \\
11.3 \\
26.8\end{array}$ & $\begin{array}{r}12.8 \\
2.6 \\
1.3 \\
3.8\end{array}$ & $\begin{array}{r}20.6 \\
9.7 \\
3.9 \\
16.8\end{array}$ \\
\hline Self-employed father & 34.8 & 30.4 & 24.4 & 42.2 \\
\hline Self-employed brothers & 33.9 & 39.1 & 26.9 & 33.3 \\
\hline $\begin{array}{l}\text { Highest level of education } \\
\text { Up to partial secondary educ. }\end{array}$ & 33.7 & 51.4 & 46.2 & 49.6 \\
\hline $\begin{array}{l}\text { Initial sources of finance } \\
\text { Family } \\
\text { Bank loans } \\
\text { Personal resources }\end{array}$ & $\begin{array}{l}21.4 \\
21.4 \\
87.4\end{array}$ & $\begin{array}{l}35.7 \\
37.1 \\
74.3\end{array}$ & $\begin{array}{l}37.7 \\
32.5 \\
74.0\end{array}$ & $\begin{array}{l}27.8 \\
46.4 \\
63.6\end{array}$ \\
\hline $\begin{array}{l}\text { Reaching first clients } \\
\text { Kinship, social relations } \\
\text { Previous business contacts }\end{array}$ & $\begin{array}{l}13.2 \\
34.9\end{array}$ & $\begin{array}{l}27.4 \\
22.6\end{array}$ & - & - \\
\hline Total (abs. no.) & 115 & 72 & 78 & 156 \\
\hline
\end{tabular}

This table does not include second-generation native Israelis. Only selected categories of some variables are presented in this table.

${ }_{b}^{a}$ Manufacturing, car repair shops, repairs and maintenance of mechanical equipment.

Retail, wholesale, food services, personal services.

cYavne, Ashqelon, Ofaqim, and Qiryat Shemona.

More than one source is possible. Thus, percentages sum up to more than 100 percent.

Source: Field survey. 
small nonmetropolitan towns, which tend to have a homogenous ethnic composition.

Location also had an independent impact on paths to entrepreneurship. The Tel Aviv metropolis was a most advantageous location for immigrant entrepreneurs in distribution and blue-collar activities, whereas immigrant entrepreneurs in white-collar services had greater locational flexibility. Entrepreneurs in blue-collar and distribution activities in large cities enjoyed better opportunities to gain relevant experience as salaried employees and a much broader range of business formation opportunities than such entrepreneurs in nonmetropolitan towns. The entrepreneurs in large cities had superior professional qualifications and financial resources. They could more often utilize previous business contacts, and their business location decisions were less determined by the place of residence and more often based on economic considerations. In nonmetropolitan areas, entrepreneurship depended much more on narrow family and social networks. Hence, the combination of a population of Eastern origin and a nonmetropolitan location created the most restricted paths to entrepreneurship. The public policy of dispersing population by establishing new, nonmetropolitan development towns relocated mainly the poorer immigrants of Eastern origin during the 1950 s and 1960 s. Since these immigrants were relatively immobile geographically, the policy had a major role in restricting their prospects for advancement through entrepreneurship.

The emerging interest in local small business development in Israel during the 1980s has been related to the increasing involvement in economic development by local authorities, who faced a stagnant economy and ineffective government action. The large wave of immigrants from the former USSR since 1989 can create a major change in "the rules of the game," whose impact on the balance of power between the central government and local authorities is yet to be seen. In any case, small business formation is given prime importance as a route of economic absorption of new immigrants in various localities because it has the advantage of requiring relatively modest public investment. This paper indicates that the realization of the entrepreneurial potential among immigrants is influenced by their geographical distribution, which determines both opportunities offered to immigrants by local economies and the existence of supportive entrepreneurial networks of various types. Potential immigrant entrepreneurs are in a disadvantageous position in nonmetropolitan towns and depend more both on kinship and ethnic networks and on public support such as vocational training and financing. A dispersed distribution of immigrants among a large number of nonmetropolitan towns further impedes their prospects for entrepreneurship by putting another obstacle in the operation of ethnic networks, which is so essential in these locations. Thus, the community setting and the paths to entrepreneurship 
specific to places and immigrant groups should be taken into account when formulating development strategies for specific localities.

\section{ENDNOTES}

1. The bulk of European immigrants arrived earlier than the bulk of Eastern origin immigrants in the 1948-1954 period. This fact had a profound impact on the spatial pattern of settlement of these two major groups, but other than that, the slight variation in length of stay in Israel cannot be expected to influence significantly their position in the labor market.

\section{REFERENCES}

Amin, A., and K. Robins. "The Re-emergence of Regional Economies? The Mythical Geography of Flexible Accumulation." Society and Space 8 (1990): 7-34.

Bamford, J. "The Development of Small Firms, the Traditional Family and Agrarian Patterns in Italy." In Entrepreneurship in Europe, edited by $\mathbf{R}$. Goffee and R. Scase, 12-25. London: Croom Helm, 1987.

Bingham, R. D., and J. E. Melkers. "Entrepreneurs in America: Are They Really a Different Breed?" Government and Policy 7 (1989): 411-422.

Birch, D. Job Creation in America: How our Smallest Companies Put the Most People to Work. New York: Free Press, 1987.

Brock, W. A., and D. S. Evans. "Small Business Economics." Small Business Economics 1(1989): 7-20.

Campbell, M., ed. Local Economic Policy. London: Cassell, 1990.

Eisenstadt, S. The Transformation of Israeli Society. London: Weidenfeld and Nicolson, 1985.

Felsenstein, D. "Assessing the Employment Effectiveness of Small Business Financing Schemes: Some Evidence from Israel." Small Business Economics 4 (1992):

Gildas, S. "Immigrant Entrepreneurs in France and European Overview." Los Angeles: UCLA, Institute for Social Science Research, 1990.

Glazer, N., and D. P. Moynihan. Beyond the Melting Pot; the Negroes, Puerto Ricans, Jews, Italian and Irish of New York City. 2d ed. Cambridge, Mass.: M.I.T. Press, 1970.

Greenwood, N. "The Nightmares of Israeli Small Business." Jerusalem: IASPS, Division for Economic Policy Research, 1990. 
Harvey, D. "From Managerialism to Entrepreneurialism: The Transformation in Urban Govemance in Late Capitalism." Geografiska Annaler 71B (1989): 3-17.

Johannisson, B. "Regional Variations in Emerging Entrepreneurial Networks."

Paper presented at the 28th European Congress of the Regional Science Association, Stockholm, 1988.

Lissak, M. "Immigration Policy in the 1950s." Idan 8 (1986): 9-18 (in Hebrew).

McCarthy, K. F., and R. B. Valdez. Current and Future Effects of Mexican Immigration in California. Santa Monica, Calif.: Rand Corporation, 1986.

Maman, D. Ethnicity, Social Status and Social Networks-Preliminary Findings. Jerusalem: The Jerusalem Institute for Israel Studies, 1991 (in Hebrew).

Martinelli, F. "Public Policy and Industrial Development in Southem Italy." International Journal of Urban and Regional Research 9 (1985): 47-81.

Mokrey, B. W. Entrepreneurship and Public Policy, Can Government Stimulate Business Startups? New York: Quorum Books, 1988.

Nahon, Y. Self-Employed Workers-the Ethnic Dimension. Jerusalem: The Jerusalem Institute for Israel Studies, 1989 (in Hebrew).

Portes, A. "Modes of Structural Incorporation and Present Theories of Labor Immigration." In Global Trends in Migration, edited by M. M. Kritz, C. B. Keely, and S. M. Tomasi, 298-319. New York: Center for Migration Studies, 1981.

Portes, A., and R. L. Bach. Latin Journey, Cuban and Mexican Immigrants in the United States. Berkeley: University of Califomia Press, 1985.

Razin, E. "Relating Theories of Entrepreneurship Among Ethnic Groups and Entrepreneurship in Space - the Case of the Jewish Population in Israel." Geografiska Annaler 71B (1989): 167-181.

. "Spatial Variations in the Israeli Small-Business Sector: Implications for Regional Development Policies." Regional Studies 24 (1990a): 149-162.

"Urban Economic Development in a Period of Local Initiative: Competition Among Towns in Israel's Southern Coastal Plain." Urban Studies 27 (1990b): 685-703.

"Entrepreneurship Among Immigrants-the Israeli Experience in an International Perspective." Paper presented at the BGU-UCLA Conference on Immigration, Beer Sheva, May 20-23, 1991a.

. "Geographical Mobility of Selected Age Cohorts of Immigrant Groups in Israel: Implications for Occupational Mobility." Paper presented at the British-Israeli Workshop on Migration and Development, sponsored by the Regional Science Association, Shefayim, June 3-5, 1991 b. 
Razin, E., and A. Langlois. "Location and Entrepreneurship Among New Immigrants in Israel and Canada." Geography Research Forum 12 (1992): forthcoming.

Rischin, M. The Promised City: New York Jews 1870-1914. Cambridge, Mass.: Harvard University Press, 1962.

Sombart, W. The Jews and Modern Capitalism. London: T.F. Unwin, 1913.

Storper, M., and A. J. Scott. "The Geographical Foundations and Social Regulation of Flexible Production Complexes." In The Power of Geography: How Territory Shapes Social Life, edited by J. Wolch and M. Dear, 21-40. Winchester, Mass.: Unwin Hyman, 1989.

Tamari, M. "Small Firms in Israel." Tel Aviv: The Israeli Center for Social and Economic Advancement, 1991 (in Hebrew).

Zimmer, C., and H. Aldrich. "Resource Mobilization Through Ethnic Networks: Kinship and Friendship Ties of Shopkeepers in England." Sociological Perspectives 30 (1987): 422-445. 